\title{
Dixie Backlash? Anti-Southern Affect and Party Support Outside the South
}

\section{Jonathan Knuckey}

The literature on partisan change in the American electorate has devoted considerable attention to explaining Republican gains in the South. Less time has been devoted to examining changes outside of the South, where a Democratic majority has persisted - and indeed grown - over the past two decades. This article examines whether the realignment toward the Republican Party in the South has resulted in a move toward the Democratic Party outside the South. Specifically, it is posited that the growing influence of the South within the Republican Party has resulted in a backlash against the GOP. Using data from the American National Election Studies, this article examines affect toward southerners as a determinant of the political behavior of non-southerners. Findings indicate that even after controlling for other explanatory variables, affect toward southerners is a significant predictor of how non-southerners evaluate the political parties, as well as vote choice in the 2008 presidential election. While partisanship and ideology remain the best predictors of vote choice among non-southerners, anti-southern backlash should not be discounted for the GOP's "Northern problem" in recent elections.

The role that the South has played in shaping partisan and electoral developments in American politics has been extensively documented. Indeed, the two foremost scholars of southern politics, Earl Black and Merle Black (1992) referred to the "Vital South" in the second of their trilogy of books that described and explained party development in the eleven states of the Old Confederacy (see also Black and Black 1987, 2002). A Republican "Solid South" was viewed as the foundation upon which the GOP was able to dominate presidential elections from 1968 for the next two decades. At the same time, when the Republican Party took control of Congress in 1994 it was largely a result of gains in the South, with white voters bringing their congressional voting behavior into line with the presidential vote choice (Black and Black 2002; Bullock et al. 2006; McKee 2010).

The drama of the South's party realignment has, perhaps, drawn attention away from partisan developments outside the South. This is not to say that partisan change in the non-South (or the "North" as it is sometimes labeled) has been ignored (see, for example, Carmines and Stanley 1992; Knuckey 2009; Marchant-Shapiro and Patterson 1995; Speel 1998; Stonecash et al. 2000; Reiter and Stonecash 2011), and, indeed, partisan change in the non-South has often been used as a means of contrast with that evident in

JONATHAN KNUCKEY is Associate Professor of Political Science at the University of Central Florida, Orlando, Florida.

The American Review of Politics, Vol. 34, Fall, 2013: 179-206

C2013 The American Review of Politics 
the South (Miller and Shanks 1996; Schreckhise and Shields 2003; Abramowitz and Knotts 2006). Moreover, moving beyond their study of southern politics, Black and Black (2007) examined partisan trends in different regions, with the Northeast and Pacific West moving toward the Democrats and the Mountain West/Plains states toward the Republicans (see also Bullock 1988; Bullock et al. 2006). Still, the literature on party and electoral politics outside the South remains fairly limited, and certainly cannot approach the rich and voluminous literature describing partisan change in the South (for an overview see Prysby 2006).

The failure of the extant literature to examine political behavior outside the South is certainly understandable. It does not-after all-have a story anywhere near as compelling as that found in the eleven states of the Old Confederacy, with a Democratic "Solid South" giving way, if not to a Republican "Solid South", to at least a region where the GOP is in the ascendancy. Yet by devoting a regional focus to the South, an important story may have been missed: the persistence of a Democratic majority outside the South. As shown in Figure 1, the Republicans have not won a majority of the popular or electoral vote in presidential elections outside the South since

\section{Figure 1. Republican Popular Vote and Electoral College Vote in Presidential Elections outside the South, 1988-2008}

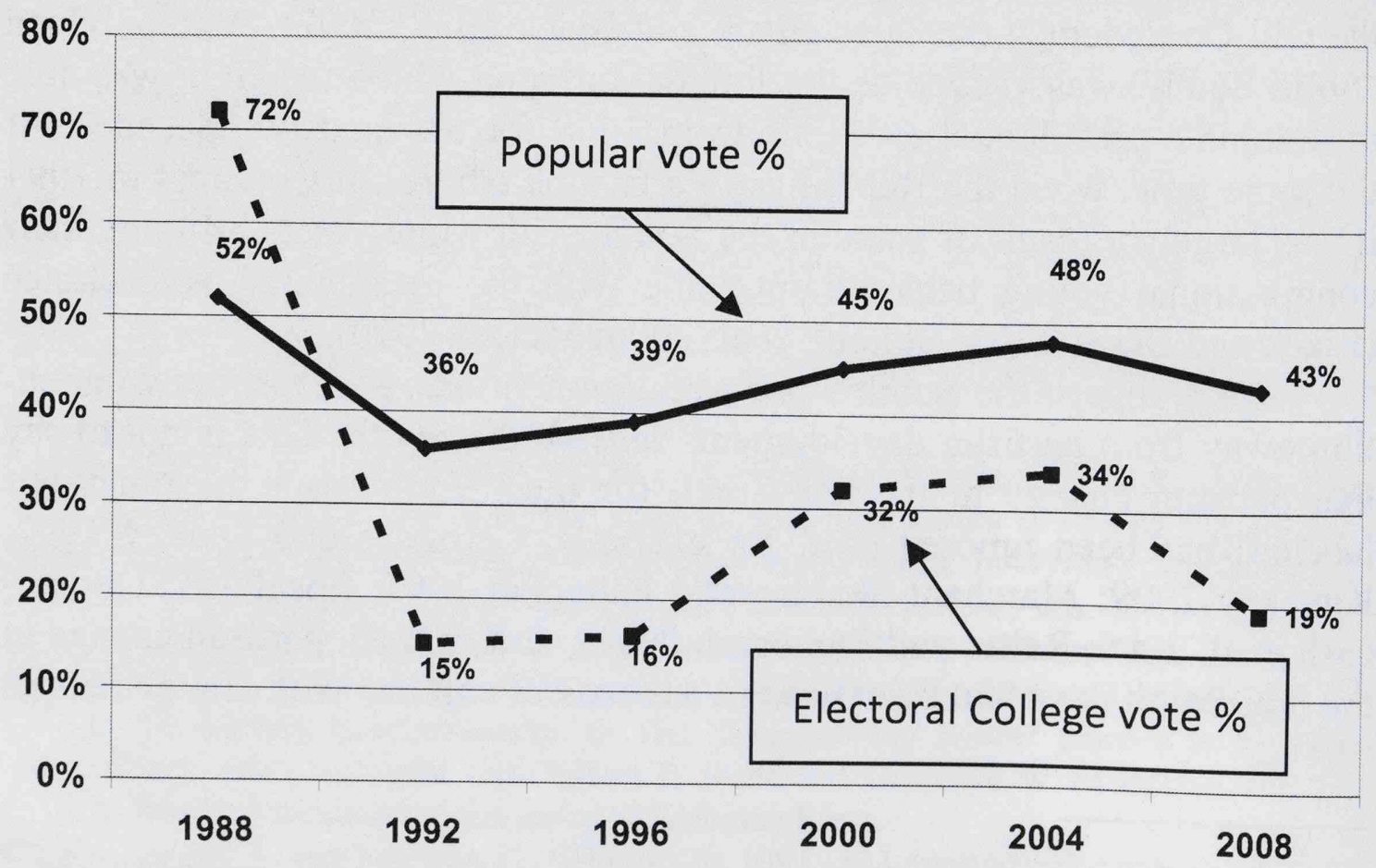

Note: Popular vote and Electoral College votes are for all states (and the District of Columbia) exclusive of Alabama, Arkansas, Florida, Georgia, Louisiana, Mississippi, North Carolina, South
Carolina, Tennessee, Texas, and Virginia.

Source: Calculated by the author from election returns. 
1988, which marked the last election of the Reagan coalition. At the same time, there has been a dramatic drop in Republican U.S. House seats outside the South. As Figure 2 shows, even when the Republicans held a majority of seats in the House, from 1994 to 2006, they did so as a minority party outside the South in three elections (1998, 2000 and 2004). In losing control of Congress in 2006, it was the loss outside the South that doomed the Republicans to minority status, while in 2008, the GOP held just over one-third of non-southern U.S. House seats. While the Republicans recovered some of their strength outside the South in the 2010 midterm elections, the GOP still remained the minority party, holding 48 percent of U.S. House seats. Again, it was its southern majorities-where the GOP now holds 72 percent of the region's U.S. House seats - that ensured a Republican controlled U.S. House of Representatives.

The goal of this article is to examine whether the Democratic advantage outside of the South has been the result of a counter-reaction to the rise of a Republican South. While the realignment of the South has often been associated with a pro-Democratic realignment in much of the non-South, a direct connection between these regional realignments-while sometimes alluded

\section{Figure 2. Republican Percentage of Seats in the U.S. House Outside the South, 1994-2008}

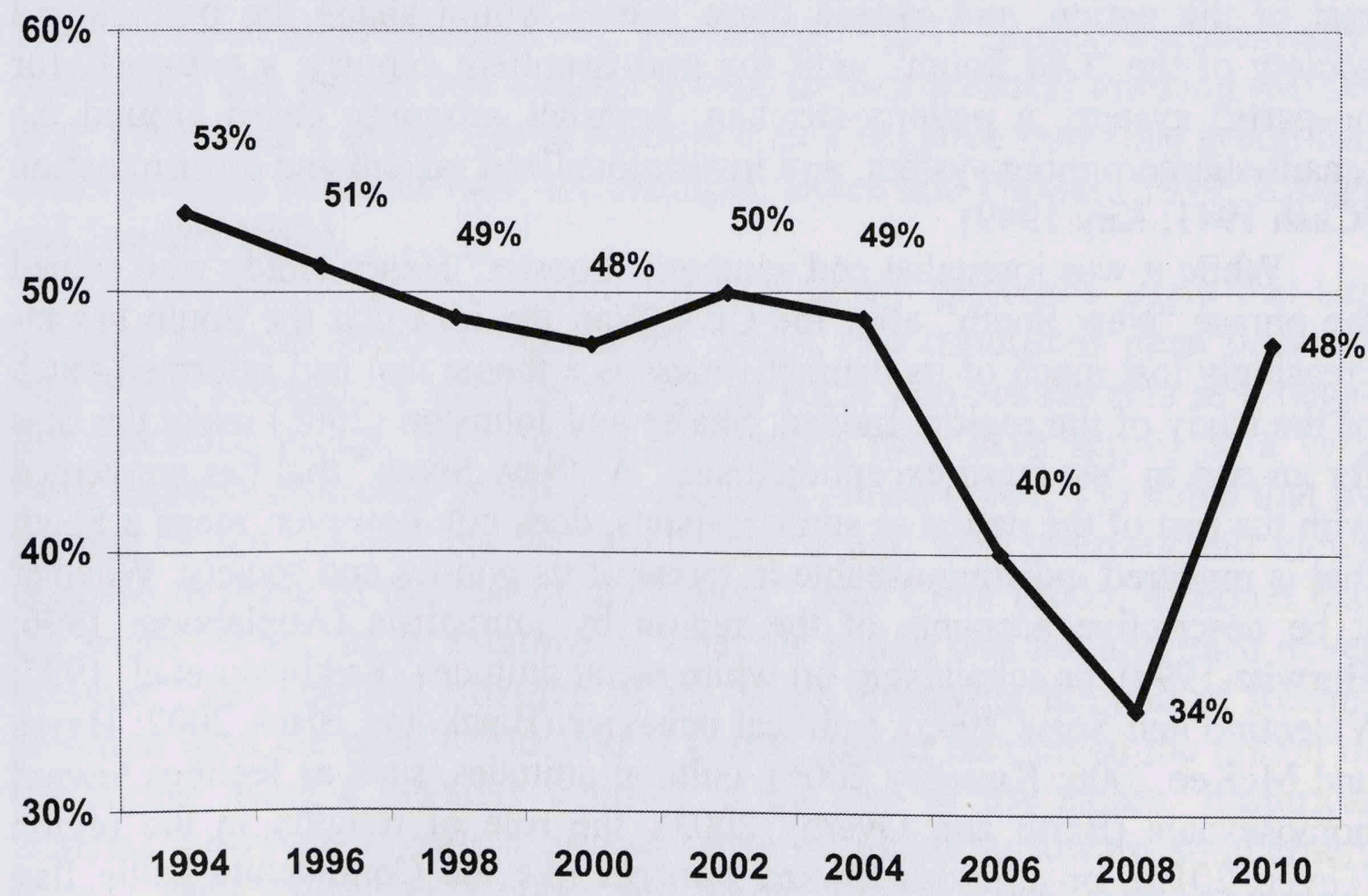

Note: Percentage of seats held are for all states exclusive of Alabama, Arkansas, Florida, Georgia, Louisiana, Mississippi, North Carolina, South Carolina, Tennessee, Texas and Virginia.

Source: Calculated by the author from election returns. 
to (see for example Caldwell 1998)-has never been fully explored. It is hypothesized that for some non-southern voters, the South and southerners are perceived as a negative reference group, and that as the Republican Party has become increasingly a party of the South, this "anti-southern" sentiment may be costing the GOP support outside the South. Specifically, using data from the American National Election Study (ANES), feeling thermometer ratings of southerners by non-southerners are analyzed in order to ascertain whether an anti-southern backlash exerts an effect-above and beyond that of other relevant explanatory variables - on the political behavior of the nonsouthern electorate.

\section{Southerners as a Negative Reference Group}

The notion that the South has historically been "different" from the rest of the United States is indisputable. Indeed, distinctiveness was evident from the early history of the South by those settlers from southern England who came not to escape religious persecution, but rather to earn wealth, and in doing so establishing a proto-feudal caste system (Fischer 1989; Cobb 2005). Those differences were further exacerbated by the emergence of the South's "peculiar institution" of chattel slavery, which supported an agrarian economy. Secession, defeat in the Civil War and the post-war Reconstruction further served to render the South, and southerners, distinguishable from the rest of the nation, and indeed these events would shape the politics and society of the "Old South" until the mid-twentieth century: a one-party (or no-party) system, a poverty-stricken, agrarian economy based around the tenant-sharecropping system, and institutionalized racism and discrimination (Cash 1941; Key 1949).

While it was journalist and southern "booster" Henry Grady who coined the phrase "New South" after the Civil War, the idea that the South has increasingly lost much of its distinctiveness is a theme that had informed much of the study of the region. Indeed, Shafer and Johnston (2006) make the case for an end to "southern exceptionalism." A "New South" that has converged with the rest of the nation in some respects, does not, however, mean a South that is rendered indistinguishable in terms of its politics and society. Whether it be descriptive accounts of the region by journalists (Applebome 1996; Horwitz 1998), or scholarship on white racial attitudes (Kuklinski et al. 1997; Valentino and Sears 2005), political behavior (Black and Black 2002; Hayes and McKee 2006; Knuckey 2006), cultural attitudes, such as feelings toward homosexuals (Barth and Overby 2003), the role of religion in the region (Green 2010), or attitudes toward symbols like the Confederate battle flag (Cooper and Knotts 2006), the South continues to exhibit important differences from the rest of the nation. Emphasizing southern distinctiveness, Reed 
(1993) argues that southerners (or more precisely white southerners) constitute an "American ethnic group." Specifically:

\begin{abstract}
Southerners, like members of immigrant ethnic communities, belong to a group defined by a historical experience, in which membership is ordinarily inherited but rests ultimately on a combination of individual identification and acceptance or categorization by others. Like other ethnic groups, Southerners have differed from the national norm: they have been poorer, less educated, more rural, occupationally specialized. They also differ culturally in important respects, and their political behavior has been distinctive. Although Southerners are not often identifiable by name or appearance, their accent usually serves as an ethnic marker. They have been stereotyped by other Americans and, indeed, are usually willing themselves to generalize about their differences from their countrymen (Reed 1993, 29).
\end{abstract}

Such a perspective suggests that southerners may potentially serve the function of a reference group, which is the theoretical approach that is drawn upon in this article. The importance of group identification and evaluations has long been stressed in studies of political behavior, and were emphasized by both the "Columbia School" (Berelson et al. 1954) and "Michigan School" (Campbell et al. 1960; 1966) approaches to voting behavior. Feelings toward groups have also been emphasized by the political psychology literature, where group affect is a heuristic used by individuals to organize their political cognitions (Brady and Sniderman 1985; Conover 1988; Conover and Feldman 1981; Hamil et al. 1985). Most consequentially, individuals link parties and societal groups in their political thinking (Miller et al. 1991), and a group that is perceived as a negative reference group can affect political behavior (see, for example, Bolce and DeMaio 1999; Kinder and Sanders 1996).

For southerners to have emerged as a salient reference group that has affected political behavior outside the South, two conditions must be satisfied. First, southerners must be viewed by some non-southerners as a negative reference group. Historically, southerners may have served as a very early negative reference group. For example, Alden $(1961,14)$ noted that by the end of the colonial era the South was "a unit with interests and views opposed to those of the rest of the Union." And Cobb $(2005,4)$ noted that the South served "as an example of what the nation was not and must never become." The political isolation of the South following the end of Reconstruction until the post-World War II period further reinforced the notion of the region being a negative contrast to the rest of the nation. Empirical analysis, however, reveals a limited sense of antipathy toward southerners (Reed 1986). Moreover, Cooper and Knotts (2012) found that southerners have received increasingly warm evaluations since mid-1960s. The concern here, however, is less about changes in feeling toward southerners, but rather 
whether those feelings, especially among those non-southerners who feel antipathy toward southerners, have become politically salient and have emerged as a determinant of political behavior.

Second, non-southerners who feel cool toward southerners must be cognizant of the latter's partisan leanings. As Bolce and DeMaio $(1999,514)$ noted, "intensely disliking a group surely increases the likelihood that an individual might want to oppose it. But only if the group is salient to an individual's political thinking can that person purposively use political means such as the ballot to express antipathy." Thus, non-southerners must perceive that southerners have become associated with the Republican Party. There is ample evidence to support the "southernization" of the Republican Party. While a Republican "southern strategy" traces its origins back to the candidacy of Barry Goldwater in the 1964 presidential election, subsequently being refined by Richard Nixon in 1968 (Black and Black 1992), the rise of southern Republicans within the party occurred from the mid-1990s onwards. The 1994 midterm elections, which marked the historic capture of Congress by the GOP, elevated southern Republicans to the major leadership positions in Congress: Newt Gingrich of Georgia as Speaker of the House, Dick Armey and Tom DeLay, both of Texas, as House Majority leader and Majority Whip, respectively, while Trent Lott of Mississippi became the Senate Majority Leader. As Abramowitz and Knotts $(2006,107)$ note, "the increasing prominence of conservative white southerners in the congressional leadership of the national Republican Party may have helped the GOP to attract conservative white southern voters, it may have alienated moderate and liberal northern white voters and reinforced the loyalty of AfricanAmericans voters to the Democratic Party."

The ascendancy of southerners within the Republican Party was further illustrated by the election of George W. Bush in 2000. In many respects Bush was the first southern Republican president. ${ }^{1}$ Indeed, Bush owed his nomination to the South, where his victory in the South Carolina primary offset a damaging double-digit loss in New Hampshire to rival John McCain. And, of course, it was Florida that enabled Bush to eke out a victory in the Electoral College despite losing the popular vote to Al Gore. The South would be vital to Bush's re-election in 2004, with a Republican "Solid South" offsetting an Electoral College and popular vote deficit to John Kerry outside the South (refer back to Figure 1). Moreover, Republican gains in the Senate in 2004 were largely attributable to a pick-up of five southern seats - in Florida, Georgia, Louisiana, North Carolina and South Carolinain which Democratic incumbents had decided not to seek reelection. As the Republicans lost Congress two years later, the southern accent within the GOP was further reinforced as the party lost support outside the South while largely retaining it in the eleven states of the Old Confederacy. 
The notion that the "southernization" of the Republican Party was perhaps costing the GOP support outside the South was noted in a regional analysis of party support by Black and Black (2007), whose prior work had emphasized the centrality of the South to Republican fortunes. For example, they concluded in The Vital South by arguing that the South "shapes the trends and sets the pace of national political outcomes and processes" (Black and Black 1992, 366). By securing the eleven states of the Old Confederacy, Republican presidential candidates could devote time and resources to Northern "battleground" states. However, in Divided America, Black and Black argue that the sectionalism now evident in voting behavior was viewed as working against the interests of the Republican Party. Specifically, a party that is so reliant on its southern base now has a "Northern problem" (Black and Black 2007, 177). Indeed, declining support outside the South goes some way towards explaining why the Republican Party has won the popular vote in just one of the presidential elections from 1992 to 2008. Taking a more polemical tone, Schaller (2006) also argues that the Republican Party dominated by the conservative South has resulted in Democratic gains outside of the region, and even advocates a Democratic "Northern Strategy" by explicitly running against a conservative Republican South.

Ten years ago Caldwell (1998) in an article entitled "The Southern Captivity of the GOP" was one of the first commentators to note the potential harm for the Republican Party outside the South of a southern-based GOP. Since then, the southern captivity of the GOP has not dissipated. Indeed, if anything, it has grown. Given this development, to what extent has an antipathy toward southerners resulted in a backlash against the Republican Party outside the South, with individuals orienting their political behavior on the basis of feeling toward southerners? It is to this question the article now turns.

\section{Data and Methods}

Data are taken from the ANES Cumulative File. As the interest is in party support outside the South, respondents are excluded from the ANES "Solid South" and also the "Border South" regions. ${ }^{2}$ The primary independent variable in the analysis is the feeling thermometer item toward southerners. ${ }^{3}$ The ANES has included this item in presidential election year surveys from 1964 through 1980 as well as in 1992, 2004 and 2008. All years will be utilized to report descriptive statistics for feeling toward southerners, and the multivariate analysis will examine 1992, 2004 and 2008. While it would have been useful to have data for every cross-section from 1992 onwards - as this period corresponds with the rise of southern influence within the Republican Party - these years do at least allow us to engage in endpoint analysis. That is, 1992 serves as a baseline against which 2004 and 
2008 can be compared, the latter years, which encompass the Bush presidency, marking the points at which southern influence within the GOP was most evident, and hence where any evidence of antipathy toward southerners should be most visible with respect to political behavior.

Using the feeling thermometer for southerners to operationalize the key independent variable in this analysis necessitates a brief discussion of the limitations of this measure. First, the story of the rise of southern Republicans is more precisely the rise of white southerners within the Republican Party. Unfortunately, the ANES has never asked any feeling thermometer items exclusively about white southerners. Second, "southerner" is a label that has increasingly been applicable to both white and black southerners, especially as the latter have come to embrace their southern identity. As the actor and native Mississippian Morgan Freeman noted, having moved from Manhattan back to the Magnolia State, "I am really a product of the South, easy-living, easy-going, quiet, gentle" (quoted in Cobb 2005, 266). Indeed, both southern and non-southern blacks have exhibited warmer feelings toward southerners since the late 1960s (Black and Reed 1982; Cooper and Knotts 2012).

Whether it is the image of a white southerner that a respondent has in his or her mind's eye when presented by the stimuli, "southerner" cannot be directly ascertained, and the limitations of the ANES item has been noted. However, one means to address this measurement issue empirically, is to determine whether feeling toward southerners forms a distinct cluster with feeling toward other social groups. Specifically, if "southerner" is taken to largely imply "white southerner," then it should be correlated with feelings toward other conservative social groups. A factor analysis of the feeling thermometer items asked by ANES for the same groups in 1992, 2004, and 2008 provides an empirical means of addressing this question (see, for example, Miller et al. 1991). Results are reported in Table $1{ }^{4}$

Three factors - a liberal factor, a conservative factor and a neutral, nonideological factor-structured social group evaluations in each year. The feeling thermometer item for southerners had its highest loading on the nonideological factor in each year. This provides some support for the notion that respondents are thinking beyond "white southerners" when presented with the stimuli. However, in each year the item also loaded on a second factor-and the loadings were not trivial - which is clearly identifiable as a conservative factor based upon the groups with their highest loadings on it: conservatives, Christian fundamentalists, big business, and the military. While the feeling thermometer item for southerners is clearly not a perfect way of capturing antipathy toward southerners or the South, the findings of the factor analysis are somewhat suggestive that when presented with the stimuli "southerner" many non-southerners are thinking about white southerners. 
Table 1. Factor Analysis of Group Feeling Thermometer, 1992, 2004, and 2008 (Non-Southern Respondents)

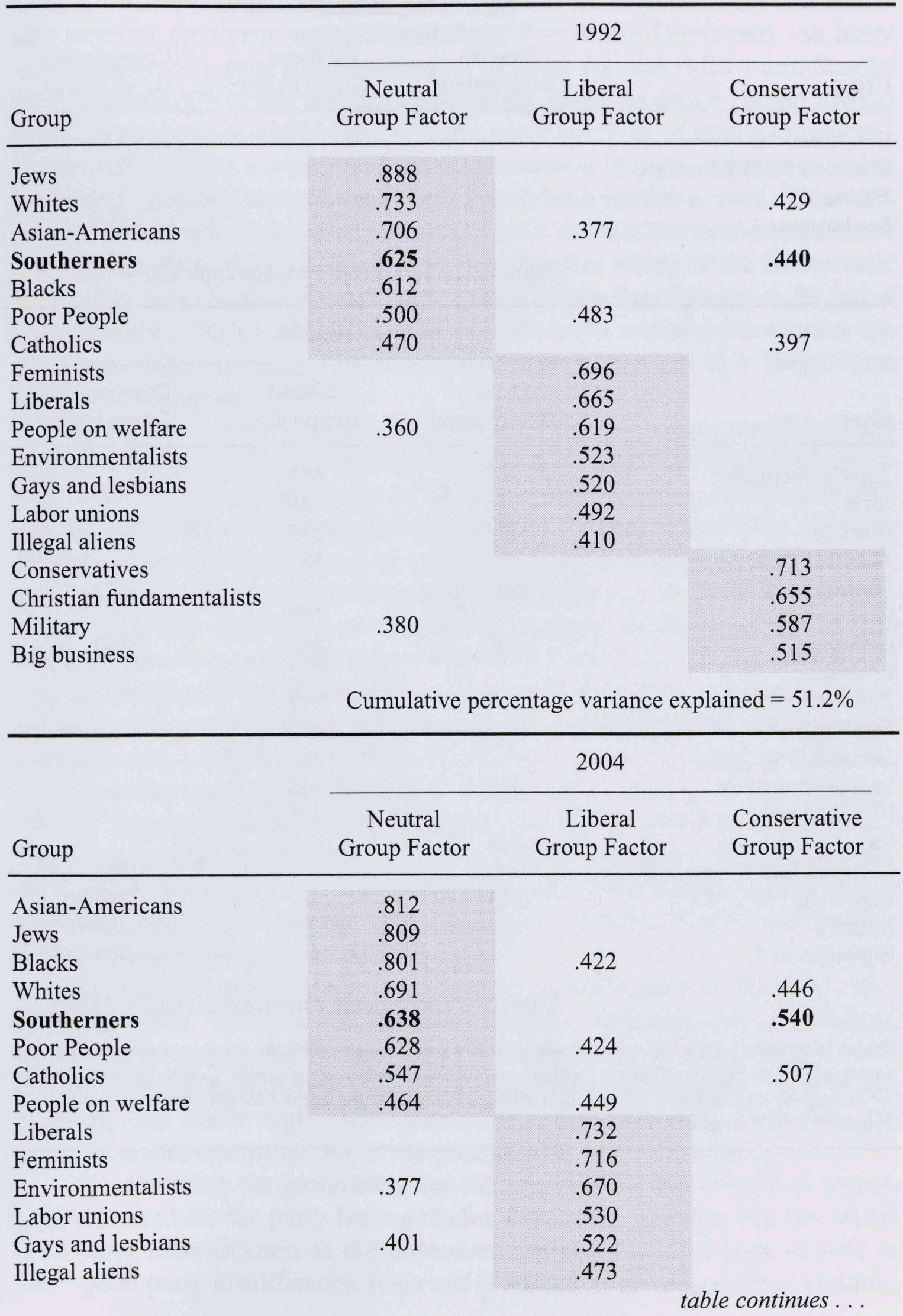


Table 1. (continued)

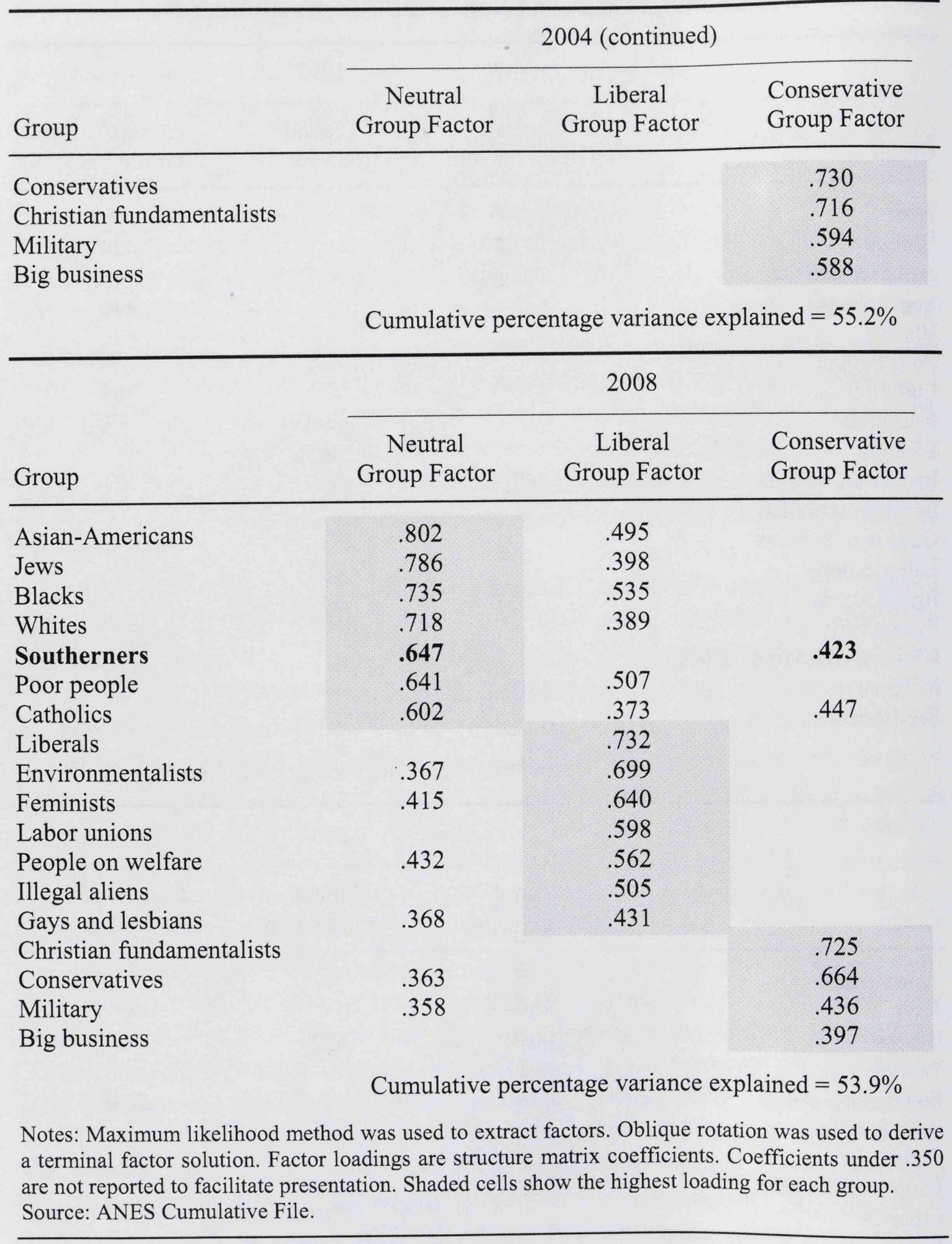


To examine the effect of feeling toward southerners on political behavior, three dependent variables are used. First, to capture the effects of feeling toward southerners on long-term party support, the 7-point party identification scale is used $(1=$ strong Republican, $7=$ strong Democrat $)$. As party identification is a more durable measure of party support (Miller and Shanks 1996; Bartels 2000), this will demonstrate the extent to which feeling toward southerners may have affected long-term party loyalties of non-southerners. ${ }^{5}$ Second, to examine a more medium-term measure of party support an index of feelings toward the Democratic and Republican parties is used. This variable was created by subtracting a respondent's feeling thermometer rating of the Republican Party from the feeling thermometer rating of the Democratic Party. The index has an actual range from 2 (most Republican) to 99 (most Democratic). Finally, the presidential vote choice is examined to capture the short-term party support. This is a dichotomous variable $(0=$ Republican vote, $1=$ Democratic vote $).{ }^{6}$

Given that demographic and other politically relevant variables may explain variation in feeling toward southerners (Cooper and Knotts 2012), as well as being rival determinants of political behavior, it is necessary to control for a number of relevant variables. These include some of the standard demographic variables utilized in studies of political behavior: race, gender, age, income, education, union household and frequency of church attendance. Given the centrality of ideology to political behavior (Levine et al. 1997; Abramowitz and Saunders 1998; Abramowtiz and Knotts 2006), the 7-point ideological identification variable is included ( 1 = extremely conservative, 7 = extremely liberal). Ideological identification is used here as a summary measure policy preferences of voters across an array of issues, as well as reflecting a more "symbolic" identification (Conover and Feldman 1981). ${ }^{7}$ To capture regional differences among the non-southern regions (see, for example Black and Black 2007), dummy variables were constructed for each of the following non-southern regions: New England, East North Central, West North Central, Mountain West, and Pacific West (the MidAtlantic region being the excluded region). ${ }^{8}$

Given the centrality of the economy to vote choice (Fiorina 1981; MacKuen et al. 1992), a retrospective measure of perceptions of national economic conditions in the previous 12 months was included as a control variable for the presidential vote choice models. An optimistic view of the economy was coded high, and a pessimistic view coded low. Party identification was also controlled for in the presidential vote choice models.

In estimating the parameters for the multivariate models, OLS regression was used for the party feelings index dependent variable. For the model with party identification as the dependent variable, ordered logit is used as the 7-point party identification scale and is treated as an ordinal-level variable, 
rather than an interval-level variable bounded at 7 . The models of vote choice were estimated using logistic regression as the dependent variable is dichotomous.

\section{Findings and Analysis}

As a preliminary to the main findings, Table 2 presents descriptive statistics for the southerner feeling thermometer item among non-southerners. This confirms the findings of Cooper and Knotts (2012) that feeling toward southerners have become warmer over time. Thus, to the extent that feeling towards southerners might affect political behavior, it was not as a result of such feelings becoming more hostile. Indeed, in 2004 and 2008, the mean thermometer rating of southerners was the highest in any of the years (66.6 and 65.1, respectively) as were the percentages who felt "very warmly" toward southerners (33.4\% and $27.7 \%$, respectively). Thus, if feeling toward southerners shapes political behavior, it likely is a result of the change in the salience of feeling toward southerners as politically relevant stimuli.

The extent to which feeling toward southerners affected each of the dependent variables is reported in Tables 3 through 5. With respect to longterm party identifications, Table 3 shows that the feeling thermometer item did not exert a statistically significant effect $(p>.10)$ in any of the years. This might be explained by the fact that party identification is more resistant to change than other attitudes and aspects of political behavior, and thus is

\section{Table 2. Feeling Thermometer Ratings of Southerners by Non-Southerners (1964-2008)}

\begin{tabular}{lcccccr}
\hline Year & $\begin{array}{c}\text { Mean } \\
\text { Rating }\end{array}$ & $\begin{array}{c}\% \\
\text { "Cold" } \\
(0-49)\end{array}$ & $\begin{array}{c}\% \\
\text { Neutral" } \\
(50)\end{array}$ & $\begin{array}{c}\text { \% "Mildly } \\
\text { Warm" } \\
(51-75)\end{array}$ & $\begin{array}{c}\text { \% "Very } \\
\text { Warm" }\end{array}$ & \\
\hline $195-97)$ & $\mathrm{N}$ \\
\hline 1964 & 58.1 & 18.8 & 36.3 & 23.2 & 21.6 & 1,063 \\
1972 & 55.1 & 21.2 & 37.6 & 23.4 & 17.8 & 1,038 \\
1976 & 60.6 & 10.9 & 34.2 & 36.3 & 18.6 & 1,290 \\
1980 & 57.3 & 11.4 & 45.4 & 31.5 & 11.7 & 1,452 \\
1992 & 61.6 & 10.0 & 34.5 & 33.7 & 21.8 & 858 \\
2004 & 62.1 & 7.1 & 38.0 & 32.5 & 22.5 & 1,419 \\
2008 & 65.6 & 7.4 & 28.1 & 29.8 & 33.4 & 674 \\
& 65.1 & 7.7 & 30.8 & 33.8 & 27.7 & 1,161
\end{tabular}

Note: Feeling thermometer scores of over $97,98,99$ and 100 are recoded by the ANES as 97 Source: American National Election Studies, Cumulative File. 
often a lagging, rather than a leading, indicator of party support. Alternatively, the large effects of ideology - consistent with the ideological realignment thesis - might have shared variance with the feeling toward southerners, and consequently might be suppressing the effects of the latter. However, running the ordered logit for each year without ideology did not result in any change for the coefficient for the southerner feeling thermometer, which still failed to achieve statistical significance $(p>.10)$ in each year.

Table 4 does, however, show that feeling toward southerners affected relative evaluations of the political parties. Indeed, in each year, the feeling thermometer item was statistically significant, even after controlling for relevant independent variables. Interestingly, the largest effect was evident in $2004(b=-.148 ; p<.01)$, which might be a reflection of having a southerner at the top of Republican ticket. Without George W. Bush at the top of the GOP ticket in 2008, the effect of feeling toward southerners was reduced by over half, although still just remaining statistically significant $(b=-.068$; $p<.10$ ). The effect of feeling towards southerners on party evaluations in 2004, while significant, should not be exaggerated. For example in 2004, a respondent who gave southerners a "cool" evaluation of 25 was predicted to be only 5 points more pro-Democratic than a respondent who gave a "warm" evaluation of 75 , holding other independent variables constant.

Table 5 shows that feeling toward southerners had no significant effect on presidential vote choice in 1992 or 2004, but it was significant in 2008 $(b=-.035 ; p<.01){ }^{9}$ On the one hand, this is puzzling, given the absence of southerners from the top of the Republican ticket in 2008. However, it does go some way to support the expectation that after eight years of a southern Republican president, southern influence within the GOP was evident and exerting an effect on vote choice above and beyond that of other explanatory variables. Given that logistic regression coefficients are not readily interpretable, Figure 3 shows the predicted probability of voting Democratic in the 2008 presidential election by manipulating the feeling thermometer across its range, while holding all other independent variables - except for raceconstant at their mean values (for continuous variables) or modal values (for categorical variables). Separate predicted probabilities are reported for blacks and non-blacks given the centrality of race in explaining political behavior in general, and specifically its large role in affecting vote choice in 2008.

Figure 3 shows feeling toward southerners had no effect on the vote choice of blacks in 2008, who approached unanimity in their support for Barack Obama. However, among non-black voters the effect of feeling towards southerners on vote choice was far from trivial. For example, a voter who felt "cold" toward southerners (given by a score of 25 on the feeling thermometer) was 32 percentage points more likely to vote for Obama in 2008 than were those who felt "warm" toward southerners (as given by a 


\section{Table 3. Effect of Feeling Towards Southerners on Party Identification (Non-southerners only)}

\begin{tabular}{|c|c|c|c|}
\hline Independent Variables & 1992 & 2004 & 2008 \\
\hline Thermometer: Southerners & $\begin{array}{l}-.004 \\
(.004)\end{array}$ & $\begin{array}{l}-.004 \\
(.005)\end{array}$ & $\begin{array}{l}-.001 \\
(.004)\end{array}$ \\
\hline Age & $\begin{array}{l}.008^{* *} \\
(.004)\end{array}$ & $\begin{array}{l}.013^{* *} \\
(.006)\end{array}$ & $\begin{array}{l}.008^{* *} \\
(.004)\end{array}$ \\
\hline Female & $\begin{array}{l}-.089 \\
(.189)\end{array}$ & $\begin{array}{l}-.093 \\
(.185)\end{array}$ & $\begin{array}{l}.173 \\
(.144)\end{array}$ \\
\hline Black & $\begin{array}{l}1.878^{* * *} \\
(.250)\end{array}$ & $\begin{array}{l}1.529 * * * \\
(.250)\end{array}$ & $\begin{array}{l}1.688 * * * \\
(.288)\end{array}$ \\
\hline Income & $\begin{array}{l}-.189 * * * \\
(.062)\end{array}$ & $\begin{array}{l}-.102 \\
(.086)\end{array}$ & $\begin{array}{l}-.190 * * \\
(.075)\end{array}$ \\
\hline Education & $\begin{array}{l}-.118^{* * *} \\
(.043)\end{array}$ & $\begin{array}{l}-.060 \\
(.072)\end{array}$ & $\begin{array}{c}.059 \\
(.057)\end{array}$ \\
\hline Church Attendance & $\begin{array}{l}-.059 * \\
(.036)\end{array}$ & $\begin{array}{l}.072 \\
(.056)\end{array}$ & $\begin{array}{l}-.047 \\
(.043)\end{array}$ \\
\hline Union Member Household & $\begin{array}{l}.588^{* * *} \\
(.154)\end{array}$ & $\begin{array}{c}.290 \\
(.219)\end{array}$ & $\begin{array}{l}.447^{* *} \\
(.193)\end{array}$ \\
\hline Ideology & $\begin{array}{l}.720 * * * \\
(.050)\end{array}$ & $\begin{array}{l}.948^{* * *} \\
(.079)\end{array}$ & $\begin{array}{l}.968^{* * *} \\
(.060)\end{array}$ \\
\hline New England & $\begin{array}{l}.505^{* *} \\
(.236)\end{array}$ & $\begin{array}{l}.438 \\
(.364)\end{array}$ & $\begin{array}{l}.205 \\
(.374)\end{array}$ \\
\hline East North Central & $\begin{array}{c}.028 \\
(.173)\end{array}$ & $\begin{array}{l}.372 \\
(.282)\end{array}$ & $\begin{array}{l}.481^{* *} \\
(.222)\end{array}$ \\
\hline West North Central & $\begin{array}{l}-.087 \\
(.202)\end{array}$ & $\begin{array}{l}.758 * * \\
(.371)\end{array}$ & $\begin{array}{l}-.079 \\
(.254)\end{array}$ \\
\hline Mountain West & $\begin{array}{l}-.532 * * \\
(.251)\end{array}$ & $\begin{array}{l}1.125 * * * \\
(.417)\end{array}$ & $\begin{array}{l}-.329 \\
(.246)\end{array}$ \\
\hline Pacific West & $\begin{array}{l}-.203 \\
(.185)\end{array}$ & $\begin{array}{l}.660^{* *} \\
(.296)\end{array}$ & $\begin{array}{l}-.093^{* *} \\
(.214)\end{array}$ \\
\hline Intercept 1 & $\begin{array}{c}-6.120^{* * * *} \\
(.462)\end{array}$ & $\begin{array}{c}-5.523 * * * \\
(.681)\end{array}$ & $\begin{array}{c}-6.448^{* * * *} \\
(.546)\end{array}$ \\
\hline Intercept 2 & $\begin{array}{l}-4.994 * * * \\
(.448)\end{array}$ & $\begin{array}{l}-4.323 * * * \\
(.680)\end{array}$ & $\begin{array}{l}-5.075^{* * *} \\
(.524)\end{array}$ \\
\hline Intercept 3 & $\begin{array}{c}-4.239 * * * \\
(.440)\end{array}$ & $\begin{array}{c}-3.260^{* * *} \\
(.644)\end{array}$ & $\begin{array}{l}-4.237 * * * \\
(.513)\end{array}$ \\
\hline Intercept 4 & $\begin{array}{c}-3.703^{* * *} \\
(.436)\end{array}$ & $\begin{array}{l}-2.950^{* * *} \\
(.641)\end{array}$ & $\begin{array}{l}-3.832 * * * \\
(.508)\end{array}$ \\
\hline Intercept 5 & $\begin{array}{l}-2.870^{* * * *} \\
(.430)\end{array}$ & $\begin{array}{l}-2.189^{* * *} \\
(.635)\end{array}$ & $\begin{array}{l}-2.685 * * * \\
(.498)\end{array}$ \\
\hline Intercept 6 & $\begin{array}{c}-1.746^{* * * *} \\
(.427)\end{array}$ & $\begin{array}{l}-1.312 * * \\
(.635)\end{array}$ & $\begin{array}{c}-1.600 * * \\
(.496)\end{array}$ \\
\hline $\begin{array}{l}\mathrm{N} \\
\text { Cox \& Snell Pseudo } \mathrm{R}^{2}\end{array}$ & $\begin{array}{l}942 \\
.337\end{array}$ & $\begin{array}{l}418 \\
.408\end{array}$ & $\begin{array}{l}(.490) \\
690 \\
.442\end{array}$ \\
\hline \multicolumn{4}{|c|}{$\begin{array}{l}{ }^{*} \mathrm{p}<.10 ; * * \mathrm{p}<.05 ; * * * \mathrm{p}<.01 \text {. } \\
\text { Notes: Unstandardized ordered logit coefficients are reported. Standard errors are reported in paren- } \\
\text { theses. Dependent variable is } 7 \text {-point party identification scale }(1=\text { strong Republican, } 7=\text { strong } \\
\text { Democrat). } \\
\text { Source: American National Election Study Cumulative File. }\end{array}$} \\
\hline
\end{tabular}


Table 4. Effect of Feeling Towards Southerners on Relative Party Evaluations (Non-southerners only)

\begin{tabular}{|c|c|c|c|}
\hline Independent Variables & 1992 & 2004 & 2008 \\
\hline Thermometer: Southerners & $\begin{array}{l}-.072^{* *} \\
(.030)\end{array}$ & $\begin{array}{l}-.148 * * * \\
(.043)\end{array}$ & $\begin{array}{l}-.068^{*} \\
(.036)\end{array}$ \\
\hline Age & $\begin{array}{l}.105^{* * *} \\
(.031)\end{array}$ & $\begin{array}{l}.125^{* * *} \\
(.049)\end{array}$ & $\begin{array}{l}.085^{* *} \\
(.037)\end{array}$ \\
\hline Female & $\begin{array}{c}1.157 \\
(1.010)\end{array}$ & $\begin{array}{c}2.162 \\
(1.622)\end{array}$ & $\begin{array}{l}2.565^{* *} \\
(1.270)\end{array}$ \\
\hline Black & $\begin{array}{l}13.692 * * * \\
(1.920)\end{array}$ & $\begin{array}{l}11.060^{* * * *} \\
(3.023)\end{array}$ & $\begin{array}{l}16.147 * * * \\
(2.304)\end{array}$ \\
\hline Income & $\begin{array}{l}-1.907 * * * \\
(.521)\end{array}$ & $\begin{array}{l}.075 \\
(.758)\end{array}$ & $\begin{array}{l}-2.599 * * * \\
(.654)\end{array}$ \\
\hline Education & $\begin{array}{l}-.613^{*} \\
(.362)\end{array}$ & $\begin{array}{c}-1.108 * \\
(.606)\end{array}$ & $\begin{array}{l}.120 \\
(.504)\end{array}$ \\
\hline Church Attendance & $\begin{array}{l}-.981 * * * \\
(.302)\end{array}$ & $\begin{array}{l}.808 \\
(.494)\end{array}$ & $\begin{array}{l}-.274 \\
(.375)\end{array}$ \\
\hline Union Member Household & $\begin{array}{l}4.682^{* * *} \\
(1.297)\end{array}$ & $\begin{array}{c}1.336 \\
(1.917)\end{array}$ & $\begin{array}{l}4.442 * * * \\
(1.668)\end{array}$ \\
\hline Ideology & $\begin{array}{l}5.734 * * * \\
(.376)\end{array}$ & $\begin{array}{l}8.980 * * * \\
(.578)\end{array}$ & $\begin{array}{l}9.047 * * * \\
(.431)\end{array}$ \\
\hline New England & $\begin{array}{c}1.825 \\
(2.002)\end{array}$ & $\begin{array}{c}-.813 \\
(3.189)\end{array}$ & $\begin{array}{c}-.813 \\
(3.189)\end{array}$ \\
\hline East North Central & $\begin{array}{c}-.191 \\
(1.469)\end{array}$ & $\begin{array}{c}1.772 \\
(2.443)\end{array}$ & $\begin{array}{c}3.230 \\
(2.443)\end{array}$ \\
\hline West North Central & $\begin{array}{c}1.154 \\
(1.736)\end{array}$ & $\begin{array}{c}2.821 \\
(3.233)\end{array}$ & $\begin{array}{c}.627 \\
(2.245)\end{array}$ \\
\hline Mountain West & $\begin{array}{l}-1.762 \\
(2.124)\end{array}$ & $\begin{array}{c}6.621^{*} \\
(3.654)\end{array}$ & $\begin{array}{l}-1.541 \\
(2.172)\end{array}$ \\
\hline Pacific West & $\begin{array}{c}.558 \\
(1.574)\end{array}$ & $\begin{array}{c}3.694 \\
(2.569)\end{array}$ & $\begin{array}{c}1.064 \\
(1.886)\end{array}$ \\
\hline Constant & $\begin{array}{l}84.131 * * * \\
(3.542)\end{array}$ & $\begin{array}{l}91.882 * * * \\
(5.490)\end{array}$ & $\begin{array}{l}95.895 * * * \\
(4.272)\end{array}$ \\
\hline $\mathrm{N}$ & 934 & 419 & 688 \\
\hline Adjusted $\mathrm{R}^{2}$ & .324 & .451 & .482 \\
\hline \multicolumn{4}{|c|}{$\begin{array}{l}{ }^{*}<.10 ; * * p<.05 ; * * * p<.01 \\
\text { Notes: Unstandardized OLS regression coefficients are reported. Standard errors are reported in } \\
\text { parentheses. Dependent variable is feeling thermometer rating of Democratic Party minus feeling } \\
\text { thermometer toward the Republican Party. } \\
\text { Source: American National Election Study Cumulative File. }\end{array}$} \\
\hline
\end{tabular}




\section{Table 5. Effect of Feeling Towards Southerners on Presidential Vote Choice (Non-southerners only)}

\begin{tabular}{|c|c|c|c|}
\hline Independent Variables & 1992 & 2004 & 2008 \\
\hline Thermometer: Southerners & $\begin{array}{c}.015 \\
(.010)\end{array}$ & $\begin{array}{l}-.010 \\
(.010)\end{array}$ & $\begin{array}{l}-.035^{* * *} \\
(.011)\end{array}$ \\
\hline Party Identification & $\begin{array}{l}1.178^{* * *} \\
(.108)\end{array}$ & $\begin{array}{l}.406^{* * *} \\
(.164)\end{array}$ & $\begin{array}{l}1.094 * * * \\
(.118)\end{array}$ \\
\hline Economic Evaluation & $\begin{array}{l}.600 * * * \\
(.190)\end{array}$ & $\begin{array}{l}1.008 * * * \\
(.197)\end{array}$ & $\begin{array}{l}-.154 \\
(.229)\end{array}$ \\
\hline Age & $\begin{array}{l}.007 \\
(.010)\end{array}$ & $\begin{array}{c}.002 \\
(.012)\end{array}$ & $\begin{array}{l}.007 \\
(.011)\end{array}$ \\
\hline Female & $\begin{array}{l}-.436 \\
(.322)\end{array}$ & $\begin{array}{l}-.072 \\
(.381)\end{array}$ & $\begin{array}{l}.727 * * \\
(.348)\end{array}$ \\
\hline Black & $\begin{array}{l}1.094 \\
(.901)\end{array}$ & $\begin{array}{c}4.242 \\
(1.634)\end{array}$ & $\begin{array}{l}4.445 * * * \\
(1.254)\end{array}$ \\
\hline Income & $\begin{array}{l}-.153 \\
(.166)\end{array}$ & $\begin{array}{c}.049 \\
(.187)\end{array}$ & $\begin{array}{l}-.178 \\
(.183)\end{array}$ \\
\hline Education & $\begin{array}{l}.019 \\
(.117)\end{array}$ & $\begin{array}{l}-.066 \\
(.144)\end{array}$ & $\begin{array}{l}-.100 \\
(.138)\end{array}$ \\
\hline Church Attendance & $\begin{array}{l}-.375^{* * *} \\
(.100)\end{array}$ & $\begin{array}{l}-.001 \\
(.115)\end{array}$ & $\begin{array}{l}.079 \\
(.108)\end{array}$ \\
\hline Union Member Household & $\begin{array}{l}.240 \\
(.393)\end{array}$ & $\begin{array}{l}.845^{*} \\
(.449)\end{array}$ & $\begin{array}{l}-.428 \\
(.424)\end{array}$ \\
\hline Ideology & $\begin{array}{l}.429 * * * \\
(.133)\end{array}$ & $\begin{array}{l}1.004 * * * \\
(.185)\end{array}$ & $\begin{array}{l}.820^{* * *} \\
(.153)\end{array}$ \\
\hline New England & $\begin{array}{l}.142 \\
(.570)\end{array}$ & $\begin{array}{l}.769 \\
(.790)\end{array}$ & $\begin{array}{l}-.069 \\
(.906)\end{array}$ \\
\hline East North Central & $\begin{array}{l}-.544 \\
(.456)\end{array}$ & $\begin{array}{l}.052 \\
(.640)\end{array}$ & $\begin{array}{l}-.152 \\
(.525)\end{array}$ \\
\hline West North Central & $\begin{array}{l}.319 \\
(.541)\end{array}$ & $\begin{array}{l}.860 \\
(.752)\end{array}$ & $\begin{array}{l}.177 \\
(.582)\end{array}$ \\
\hline Mountain West & $\begin{array}{l}.310 \\
(.728)\end{array}$ & $\begin{array}{l}.310 \\
(.728)\end{array}$ & $\begin{array}{c}.536 \\
(.558)\end{array}$ \\
\hline Pacific West & $\begin{array}{l}-.409 \\
(.520)\end{array}$ & $\begin{array}{l}-.409 \\
(.520)\end{array}$ & $\begin{array}{c}.902 * \\
(.522)\end{array}$ \\
\hline Constant & $\begin{array}{l}-4.706^{* * *} \\
(1.578)\end{array}$ & $\begin{array}{c}-.528 \\
(1.880)\end{array}$ & $\begin{array}{l}1.648 \\
(1.522)\end{array}$ \\
\hline $\begin{array}{l}\mathrm{N} \\
\text { Cox \& Snell Pseudo } \mathrm{R}^{2}\end{array}$ & $\begin{array}{l}625 \\
.596\end{array}$ & $\begin{array}{l}357 \\
.542\end{array}$ & $\begin{array}{l}451 \\
.598\end{array}$ \\
\hline
\end{tabular}

$* \mathrm{p}<.10 ; * * \mathrm{p}<.05 ; * * * \mathrm{p}<.01$

Notes: Unstandardized logit coefficients are reported. Standard errors are reported in parentheses. Dependent variable is presidential vote choice ( $1=$ Democratic, $2=$ Republican). Source: American National Election Study Cumulative File. 


\section{Figure 3. Feeling Toward Southerners and Predicted Probability of Voting Democratic in the 2008 Presidential Election (Non-southerners)}

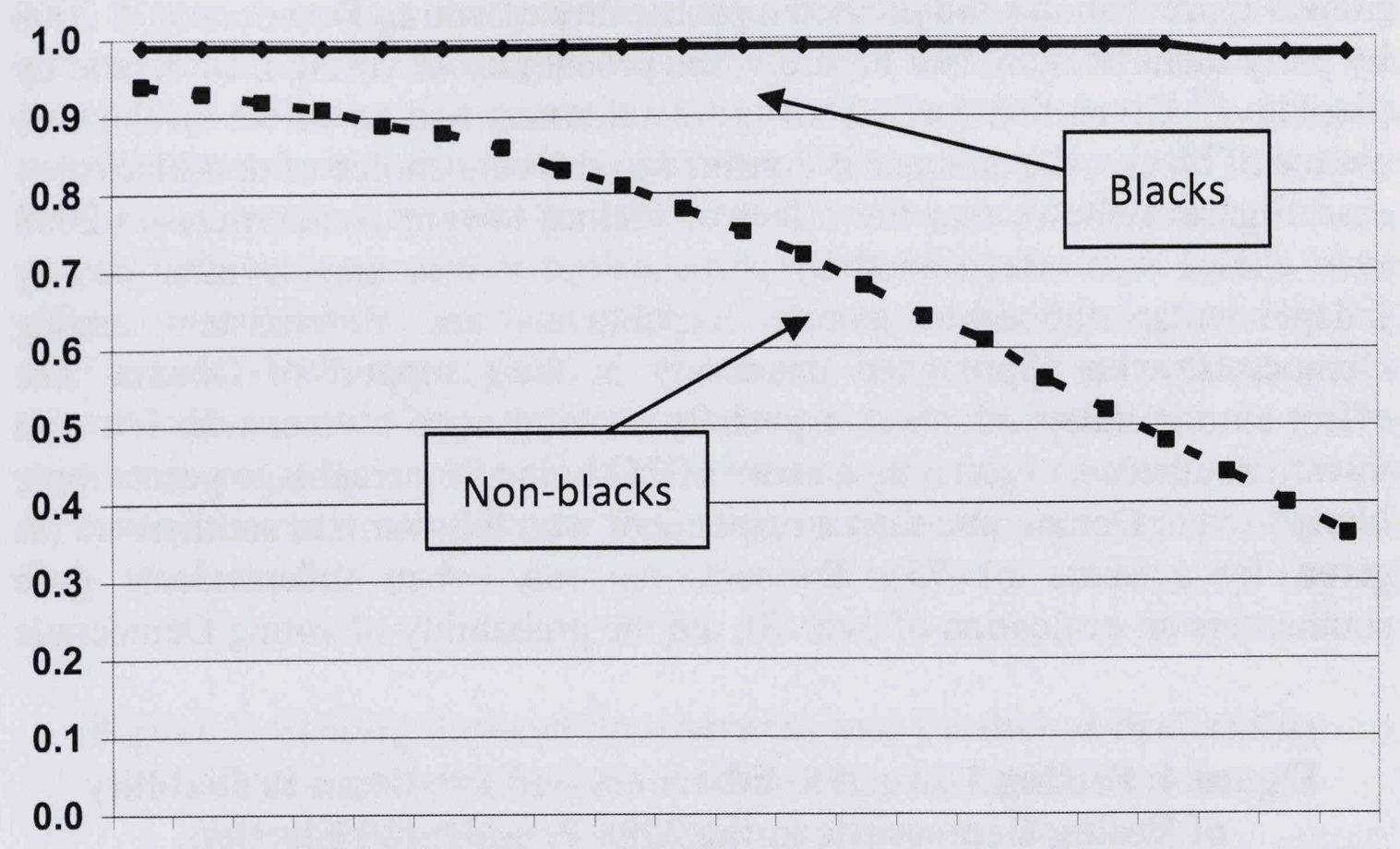

$0 \quad 5 \quad 101520253035404550556065707580859095100$

Feeling thermometer rating of southerners

Note: Predicted probabilities were calculated using the coefficients from the logistic regression in Table 5. The feeling thermometer for southerners was manipulated across its range, while all other independent variables (except for race) were held constant at their mean or modal values.

score of 75), even though these voters were comparable in every other respect. Moreover, even a voter who felt neutral toward southerners (as given by a score of 50) was some 19 percentage points more likely to have voted for Obama than one who felt warm toward southerners. However, it should be noted that irrespective of the feeling toward southerners in 2008, most voters outside the South were still more likely to vote for Obama than McCain in 2008. Indeed, only when feelings toward southerners were extremely warm (given by a score of over 80 ) did the probability of a Democratic vote drop below 50 percentage points. However, only 12 percent of respondents gave southerners such a warm rating. Thus, to the extent that antipathy toward southerners was important to vote choice in 2008 , it was in turning a likely vote for Obama into an almost certain vote for Obama.

Given the importance of party identification and ideology in explaining vote choice in 2008 - and the effect of both variables more generally on political behavior - a further consideration is to assess the extent to which feeling toward southerners mediated or reinforced partisan and ideological voting. This also allows for an examination of how feeling toward southern- 
ers may have been an important consideration for independents and moderates, two groups of "swing voters" that are often critical in determining elections. Figure 4 shows the predicted probability of voting Democratic in 2008 by party identification, and Figure 5 , the probability of voting Democratic by ideology. ${ }^{10}$ Given that feeling toward southerners had no effect on the vote choice of blacks, the analysis is confined to the vote choice of non-blacks.

Figure 4 shows that the effect of feeling toward southerners on 2008 vote choice was conditioned by partisanship: it was most evident among independents, noticeable among Republicans and non-existent among Democrats, who approached unanimity in their support of Obama. The effect among independents is especially striking, with a voter who felt cool toward southerners (given by a score of 25 ) being 36 percentage points more likely to vote Democratic than a respondent who felt warm to southerners (as given by a score of 75). Furthermore, only when independents gave southerners an evaluation of over 70 , did the probability of voting Democratic

\section{Figure 4. Feeling Toward Southerners and Predicted Probability of Voting Democratic in the 2008 Presidential Election, Controlling for Party Identification (Non-southern whites only)}

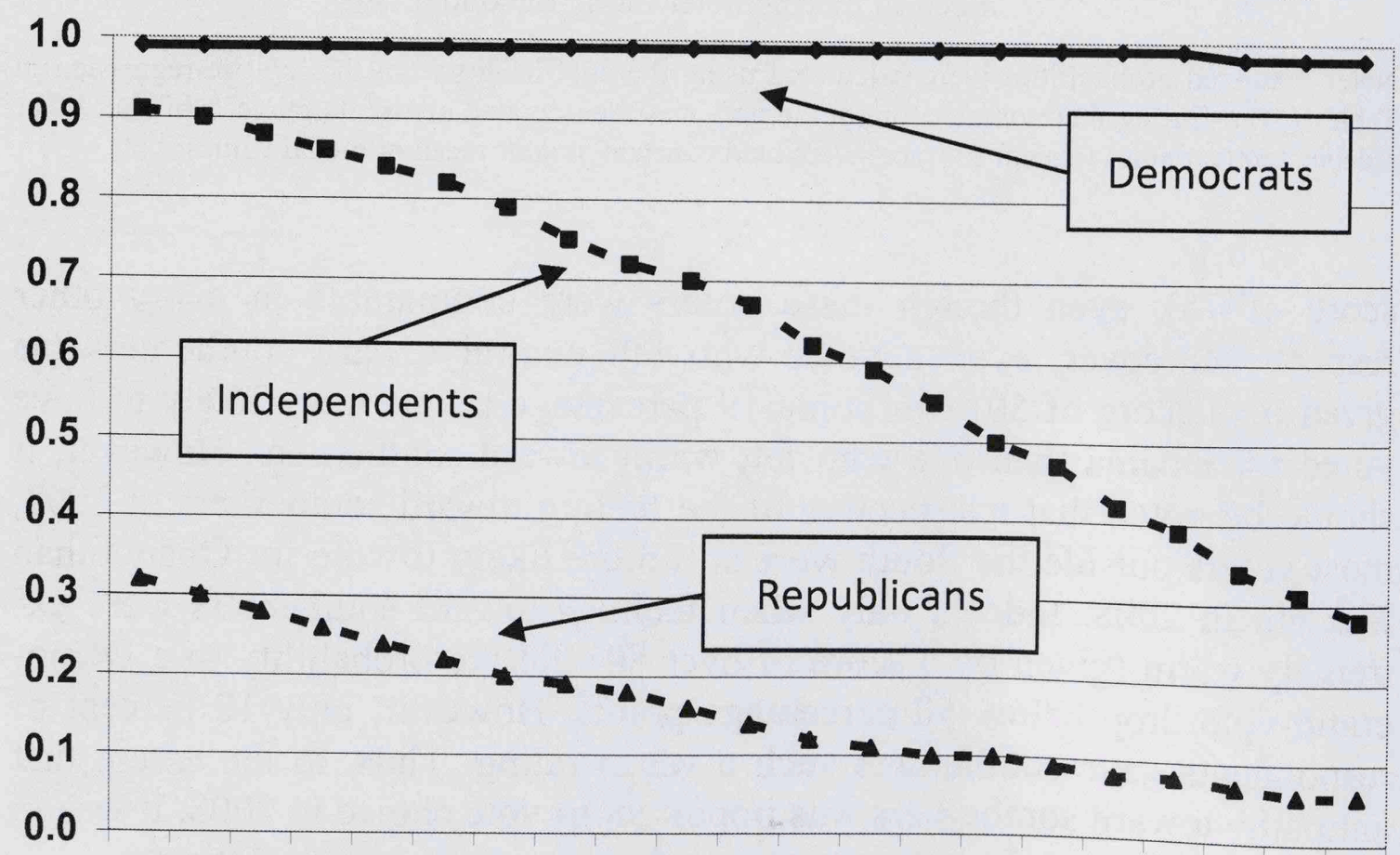

$0 \quad 5101520253035404550556065707580859095100$ Feeling thermometer rating of southerners

Note: Predicted probabilities were calculated using the coefficients from the logistic regression in Table 5. The feeling thermometer for southerners and party identification were manipulated across their range, while all other independent variables (except for race) were held constant at their mean
or modal values. 
dropped below 50 percent; yet only around one-in-five independents held such a warm evaluation of southerners.

Figure 5 reveals that ideology also conditioned the effect of feeling toward southerners. Among liberals there was virtually no effect on the probability of voting Democratic. As with Democratic identifiers, liberals approached unanimity in their support for Obama, irrespective of how they felt toward southerners. On the other hand, among moderates, and, perhaps surprisingly, among conservatives, evaluations of southerners had a large effect on the predicted probability of voting Democratic. Moderates who felt cool toward southerners (given by a score of 25) were 27 percentage points more likely to vote Democratic than a respondent who felt warm to southerners (as given by a score of 75). However, moderates at almost all levels of feeling towards southerners were still more likely to vote Democratic. Only when moderates felt exceptionally warm toward southerners (rating

Figure 5. Feeling Toward Southerners and Predicted Probability of Voting Democratic in the 2008 Presidential Election, Controlling for Ideology (Non-southern whites only)

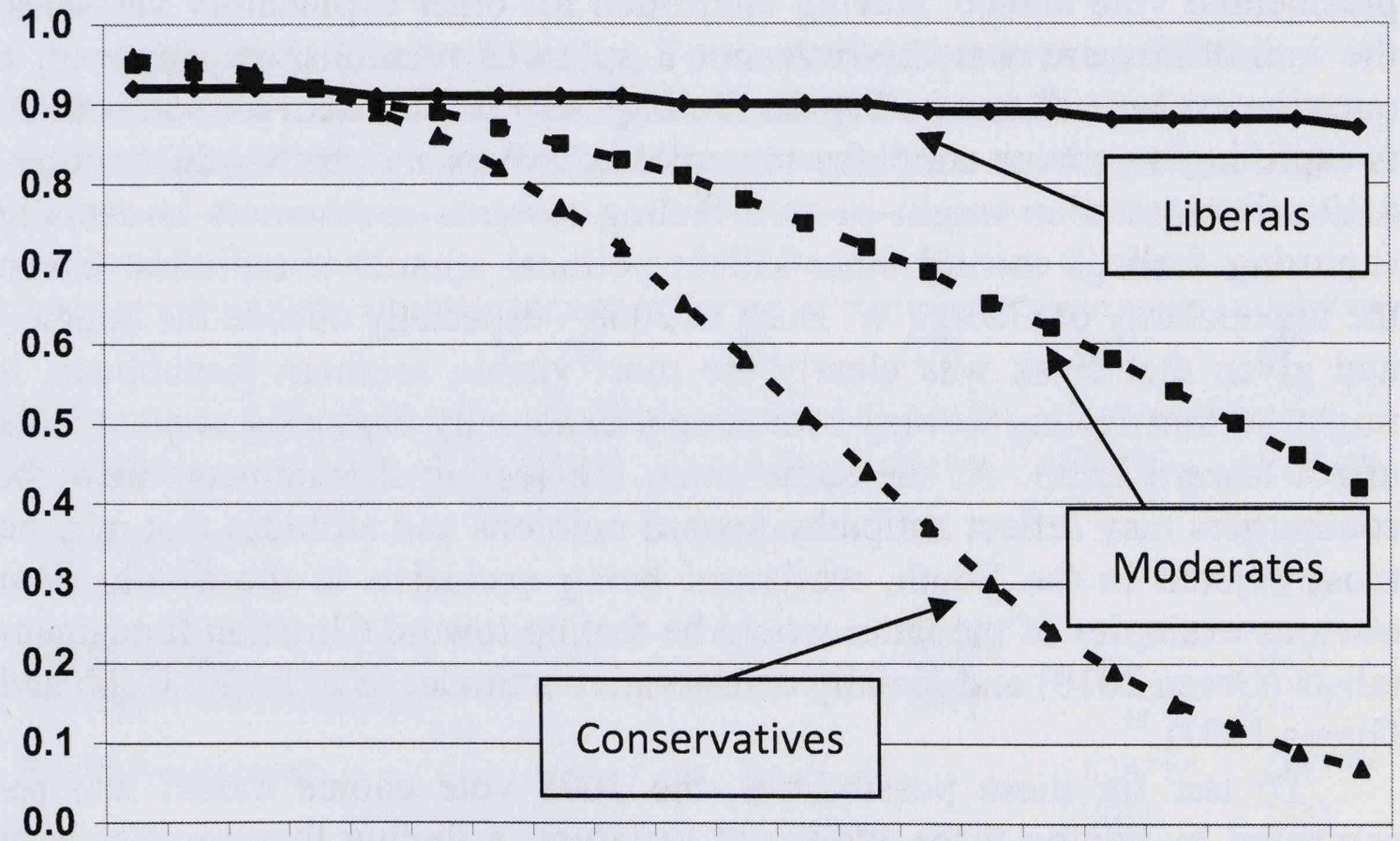

$0 \quad 5101520253035404550556065707580859095100$

Feeling thermometer rating of southerners

Note: Predicted probabilities were calculated using the coefficients from the logistic regression in Table 5. The feeling thermometer for southerners and ideology were manipulated across their range, while all other independent variables (except for race) were held constant at their mean or modal values. 
over 90) did the predicted probability of voting Democratic drop under 50 percent, but only 3 percent of moderates felt this warmly toward southerners. Perhaps most surprising is the large effect of feeling toward southerners on vote choice among conservatives. A conservative who felt cool (given by a score of 25) toward southerners was 62 percent more likely to vote Democratic than one who felt warm toward southerners (as given by a score of 75). Indeed, conservatives had over a 50 percent predicted probability of voting Democratic when their feeling thermometer rating of southerners dropped below 55. This is all the more impressive, given that almost onethird of conservatives gave southerners a rating of 55 and below. Thus nonsouthern conservatives emerge as an important source of possible vote defections in 2008 - from a "normal" Republican vote-based upon their feeling toward southerners.

\section{Is it Really Antipathy Toward Southerners?}

The preceding analysis finds evidence to support the hypothesis that feeling toward southerners may be affecting political behavior outside the South, specifically in terms of evaluations of parties, and, at least in 2008, presidential vote choice. Having controlled for other explanatory variables, the indications are that this was not a spurious relationship. However, a question remains as to whether the feeling thermometer item for southerners is capturing a genuine antipathy toward southerners and the South. An alternative interpretation might be that feeling towards southerners is actually capturing feelings toward other salient political stimuli or attitudes. Given the unpopularity of George W. Bush in 2008-especially outside the Southand given that Bush was clearly the most visible southern Republican, it might be that feeling toward southerners is actually capturing some of this affect toward Bush. At the same time, the feeling thermometer item for southerners may reflect antipathy toward opinions and attitudes that may be most evident in the South, while not being exclusive to the South. Two obvious examples of the latter would be feeling toward Christian fundamentalists (Green 2010) and racially conservative attitudes (Kuklinski, Cobb and Gilens 1997). ${ }^{11}$

To test for these possibilities, the 2008 vote choice model was reestimated by adding three additional variables: a feeling thermometer item for George W. Bush, a feeling thermometer item for Christian fundamentalists and a measure of racial resentment. ${ }^{12}$ Table 6 shows the extent to which each of these variables, both separately and collectively, affected the coefficient for the feeling thermometer item for southerners. Equation I shows the same coefficient for the feeling thermometer item for southerners from Table 5, and is the baseline against which the effects of the addition of the 
new variables can be compared. If feeling toward southerners is, in fact, capturing a more short-term antipathy toward George W. Bush, or a more long-term association with the religious and racial conservatism of the South, then affect toward southerners should wash out when these variables are entered into the equation. Table 6 also includes the same control variables from Table 5, although these are not reported.

Table 6 shows that when feeling toward Bush was added (Equation II), the coefficient for feeling toward southerners actually increased. However, feeling toward Christian fundamentalists and racial resentment (Equations III and IV) somewhat mediated the effect of feeling toward southerners on vote choice in 2008, although not to the point where the coefficient was no longer statistically significant. Moreover, even when all three additional variables were added together, the coefficient for the southerner feeling thermometer retained significance, albeit at the .10 level. Feeling toward southerners outside the South is, to some extent, reflecting an association between the southerners and Christian fundamentalism and racial resentment, but there still remains an antipathy toward southerners that cannot be explained away by these other variables.

\section{Table 6. Effect of Feeling Towards Southerners on 2008 Presidential Vote Controlling for Feeling Toward Bush, Christian Fundamentalists, and Racial Resentment (Non-southerners only)}

\begin{tabular}{|c|c|c|c|c|c|}
\hline \multirow[t]{2}{*}{ Independent Variables } & \multicolumn{5}{|c|}{2008 Presidential Vote Choice } \\
\hline & (I) & (II) & (III) & (IV) & $(\mathrm{V})$ \\
\hline $\begin{array}{l}\text { Thermometer: } \\
\text { Southerners }\end{array}$ & $\begin{array}{l}-.035 * * * \\
(.011)\end{array}$ & $\begin{array}{l}-.043 * * * \\
(.013)\end{array}$ & $\begin{array}{l}-.023 * * \\
(.012)\end{array}$ & $\begin{array}{l}-.030 * * * \\
(.011)\end{array}$ & $\begin{array}{l}-.026^{*} \\
(.014)\end{array}$ \\
\hline $\begin{array}{l}\text { Thermometer: } \\
\text { George W. Bush }\end{array}$ & - & $\begin{array}{l}-.059 * * * \\
(.009)\end{array}$ & - & - & $\begin{array}{l}-.052 * * * \\
(.010)\end{array}$ \\
\hline $\begin{array}{l}\text { Thermometer: } \\
\text { Christian Fundamentalists }\end{array}$ & - & - & $\begin{array}{l}-.022 * * \\
(.010)\end{array}$ & - & $\begin{array}{l}-.015 \\
(.011)\end{array}$ \\
\hline Racial Resentment & - & - & - & $\begin{array}{l}.826^{* * * *} \\
(.201)\end{array}$ & $\begin{array}{l}.666^{* * *} \\
(.235)\end{array}$ \\
\hline
\end{tabular}

Notes: Unstandardized logit coefficients are reported. Standard errors are reported in parentheses. Dependent variable is presidential vote choice $(1=$ Democratic, $0=$ Republican $)$. Equation I reports the coefficient for the feeling thermometer item for southerners from Table 5. The same control variables from Table 5 were also included in Equations II through V.

Source: American National Election Study Cumulative File. 


\section{Conclusions}

The correlates of party support outside the South have not been subject to as an extensive analysis as those in the South. This research sought to address this gap in the literature on regional partisan change. Specifically, it addressed one question that has not been explored in a systematic fashion: did the party realignment in the South, which resulted in the increasing prominence of southerners within the Republican Party, actually cost the GOP support outside the South?

The findings of the article provide some mixed answers to this question. Specifically, feeling toward southerners was not a determinant of party identification. The long-term, durable nature of party identification will make it resistant to change based on affect toward groups. It should be acknowledged that conceivably the direction of causality might run in the other direction, i.e., party identification affects feeling toward southerners. However, evaluations of the political parties, which offers a more mediumterm assessment of party support, were shaped by feeling toward southerners in each of the years analyzed, being most evident in 2004. Perhaps most consequentially, presidential vote choice in 2008 was affected by feeling towards southerners. It was among independents, moderates, and, perhaps most surprisingly, conservatives, where the largest effects were visible. The robustness of these findings are underscored by the fact that feeling toward southerners had an effect even after controlling for a variety of other explanatory variables that could affect vote choice.

The findings of the article also have more general implications about the distinctiveness of the South or "southern exceptionalism." As noted, feeling toward southerners exhibited by non-southerners have certainly become warmer over time. However, the findings presented here suggest that for some voters outside the South, negative-or at least neutral-affect toward southerners are consequential for political behavior.

Furthermore, affect toward southerners is not a proxy for feelings toward other groups or issues preferences that might be associated with the South. Further research, however, might probe more carefully the nature of this anti-southern affect in order to ascertain whether non-southerners are using feeling toward southerners to impute a much broader set of characteristics to the stimuli "southerner." Said differently, what is it about the South and southerners that non-southerners are reacting against? On the one hand, it could be the reawakening of sectional division, and a more long-term, diffuse antipathy toward the South as a region. Alternatively, anti-southern affect might be more particular, specifically capturing hostility toward the political influence of the South within the modern Republican Party. Determining whether a "southern schemata" exists among voters outside the South would be a productive avenue for future research. 
Of course it is important to underscore some limitations of this research. First, the feeling thermometer item for southerners is a crude means to measure the phenomenon that is of interest. Specifically, the term "southerner" may no longer be synonymous with "white southerner" both inside and outside the South. Deriving different operational definitions of affect toward the South and southerners certainly seems desirable. Second, it should be noted that the findings presented indicate that to the extent that antipathy toward southerners is affecting political behavior, it is likely to be most consequential among a relatively small part of the electorate outside the South. Indeed, the findings confirmed that party identification, ideology and race are the leading determinants of vote choice outside the South in recent presidential elections. Of course, in a party system where support is quite evenly divided, even small segments of the electorate can be consequential in tipping electoral outcomes in one partisan direction. This is especially true in presidential elections, where a handful of swing states can make the difference in deciding the outcome of the election. The Republican Party's "southern problem" among some voters outside of the South may, in some instances, be decisive for the Democrats in key battleground states.

Finally, a note of caution should be offered about generalizing too much from the findings reported. For example, it was found that feeling toward southerners was a statistically significant predictor of presidential vote choice in just one presidential election. Certainly there might be potential for feeling toward southerners to shape political behavior in the future, but this will largely be conditioned by the extent and visibility of southern influence within the Republican Party. Following the 2008 presidential election there was at least a perception that the GOP was turning into a southern regional party, one that was largely based on the finding that most of the counties that bucked the national trend and move in a pro-Republican direction in 2008 were in the South (see, for example, Nossiter 2008). On the other hand, the Republicans did make major gains outside of the South in the 2010 midterm election. And, in 2012 former Massachusetts governor Mitt Romney won the GOP nomination. Among those he defeated were southerners Rick Perry and Newt Gingrich. Moreover, Romney's running mate, Representative Paul Ryan of Wisconsin gave the GOP ticket a distinctly non-southern accent. Still, the electoral base of the modern Republican Party is the South, and the anti-southern affect suggested in this article may continue regardless of who leads the party. ${ }^{13}$ Certainly, it would be important to study the effects of anti-southern affect over more elections.

In concluding, the findings raise more questions than they answer. It would behoove scholars examining party support outside the South to take into account the role that anti-southern affect plays in shaping political behavior. Substantively, our findings are suggestive that the "rise of 
southern Republicans" may not have been without consequences outside the South. A Republican Party that maintains a strong southern accent-both literally and figuratively - may find its appeal limited outside of its regional base.

\section{NOTES}

${ }^{1}$ George H. W. Bush's home state was, of course, Texas. However, politically and culturally he may be considered less a genuine "southerner" than his son.

${ }^{2}$ The ANES Solid South region includes respondents in: Alabama, Arkansas, Florida, Georgia, Louisiana, Mississippi, North Carolina, South Carolina, Texas, and Virginia. The Border South includes: Kentucky, Maryland, Oklahoma, Tennessee, Washington D.C., and West Virginia. Conventionally, the Border South (with the exception of Tennessee) was frequently included as part of the "North" or "Non-South." However, with the exceptions of Maryland and D.C., these states in many ways have rejoined the "Political South," having voted Republican in three consecutive elections. Moreover, because feeling toward southerners would likely be more positive in the Border South, exclusion of the region seems prudent.

${ }^{3} \mathrm{~A}$ feeling thermometer asks respondents to evaluate a group on a scale ranging from 0 (the most negative affect) to 100 (the most positive), and 50 denoting a neutral midpoint. However, the ANES recodes responses of 97, 98, 99, and 100 for all group thermometers as 97 . While feeling thermometers suffer from a positivity bias (Wilcox et al. 1989), this tends to affect mainly liberal social groups. An adjusted thermometer score for feeling toward southerners was calculated by subtracting the mean scores of the other social groups from the feeling thermometer for southerners. Using this measure did not alter any of the substantive findings in the analyses reported.

${ }^{4}$ As the goal here is to explore whether feeling toward southerners form a cluster with feelings toward other groups, exploratory factor analysis is preferred over principal components analysis. A maximum likelihood method is used for the extraction of factors given that the distribution of the feeling thermometer items did not severely violate the assumption of multivariate normality. Oblique rotation was used to derive a terminal solution as it seems unlikely that the underlying factors to emerge from the analysis would be uncorrelated. The initial factor analysis for 1992 resulted in four factors being extracted. However, the eigenvalue for the fourth factor barely exceeded one, and the highest substantive loading was .533. Thus we imposed a three factor solution for 1992 . For 2004 and 2008, only three factors had eigenvalues of one, which suggests that the fourth factor in 1992 was, indeed, noise.

${ }^{5}$ The direction of causality could conceivably be reversed here, with party identification affecting feeling towards southerners (see, for example, Cooper and Knotts 2012). However, theoretically the social-psychological model implies that group affectwhether it be negative or positive - should be causally prior to party identification in the "funnel of causality" (Campbell et al. 1960).

${ }^{6}$ To facilitate a direct Democratic/Republican comparison across the three presidential elections analyzed, Perot voters were excluded from the analysis for 1992.

${ }^{7}$ Specific policy-issues areas were not used, as the same policy items have not been asked consistently over time by the NES surveys. Furthermore, given the ideological realignment of the electorate, many of the specific policy items are likely to exhibit high 
correlations - with the ideology variable and with each other-introducing the problem of multicollinearity.

${ }^{8}$ New England states: Connecticut, Maine, Massachusetts, New Hampshire, Rhode Island, and Vermont. East North Central states: Illinois, Indiana, Michigan, Ohio, and Wisconsin. West North Central states: Iowa, Kansas, Minnesota, Missouri, Nebraska, South Dakota, and North Dakota. Mountain West States: Arizona, Colorado, Idaho, Montana, Nevada, New Mexico, Utah, and Wyoming. Pacific West states: California, Oregon, and Washington.

${ }^{9}$ Comparable models of vote choice were also analyzed for every presidential election year prior to 1992 in which the feeling thermometer item for southerners was asked, i.e., 1964-1980. In no year was the southerner feeling thermometer statistically significant $(\mathrm{p}>.10)$.

${ }^{10}$ The predicted probability for Democrats (Republicans) in Figure 4 is the average across strong, weak and Independent-leaning Democrats (Republicans). The predicted probability for liberals (conservatives) is the average across those who were slightly liberal (conservative), liberal (conservative) or strongly liberal (conservative).

${ }^{11} \mathrm{~A}$ variable that measured affect toward the conservative groups shown in Table 1 was also included, utilizing the standardized factor score for the conservative group factor in 2008. However, this variable exhibited a very high correlation with the ideological identification variable $(r=.745, p<.01)$, which raises the issue of multicollinearity, thus this variable was dropped from the subsequent analysis.

${ }^{12} \mathrm{Racial}$ resentment scale was based on the following four questions, where respondents were asked to indicate whether they agreed or disagreed, and how strongly they did so: (1) Irish, Italian, Jewish and many other minorities overcame prejudice and worked their way up. Blacks should do the same without any special favors; (2) Generations of slavery and discrimination have created conditions that make it difficult for blacks to work their way out of the lower class; (3) It's really just a matter of some people trying hard enough; if blacks would only try harder they could be just as well off as whites; (4) Over the past few years blacks have gotten less than they deserve. All the items were coded for consistency, with a racially sympathetic response coded low, and a racially resentful response coded high. The four variables explained 58.7 percent of the cumulative variance, with an eigenvalues of 2.349 . The resulting standardized factor score was then utilized in the analysis.

${ }^{13} \mathrm{As}$ in 2008 , the importance of anti-southern effect among non-southern voters would be further demonstrated if feeling toward southerners had an effect on vote choice in the 2012 presidential election, despite the absence of a southerner on the Republican presidential ticket.

\section{REFERENCES}

Abramowitz, Alan I., and H. Gibbs Knotts. 2006. Ideological Realignment in the American Electorate: A Comparison of Northern and Southern Voters in the Pre-Reagan, Reagan and Post-Reagan Eras. Politics and Policy 34(4):94-108.

Abramowitz, Alan I., and Kyle L. Saunders. 1998. Ideological Realignment in the U.S. Electorate. Journal of Politics 60(1):634-652.

Alden, John Richard. 1961. The First South. Baton Rouge: Louisiana State University Press. 
Applebome, Peter. 1996. Dixie Rising: How the South is Shaping American Values, Politics, and Culture. New York: Times Books.

Barth, Jay, and L. Marvin Overby. 2003. Are Gay Men and Lesbians in the South the New "Threat"?: Regional Comparisons of the Contact Theory. Politics and Policy 31(3):452-470.

Bartels, Larry M. 2000. Partisanship and Voting Behavior, 1952-1996. American Journal of Political Science 44(1):35-50.

Berelson, Bernard, Paul Lazarsfeld, and William McPhee. 1954. Voting. Chicago: University of Chicago Press.

Black, Earl, and Merle Black. 1987. Politics and Society in the South. Cambridge, MA: Harvard University Press.

Black, Earl, and Merle Black. 1992. The Vital South. Cambridge, MA: Harvard University Press.

Black, Earl, and Merle Black. 2002. The Rise of Southern Republicans. Cambridge, MA: Belknap Press.

Black, Earl, and Merle Black. 2007. Divided America: The Ferocious Power Struggle in American Politics. New York: Simon and Schuster.

Black, Merle, and John Shelton Reed. 1982. Blacks and Southerners: A Research Note. Journal of Politics 44(1):165-171.

Bolce, Louis, and Gerald DeMaio. 1999. The Anti-Christian Fundamentalist Factor in Contemporary Politics. Public Opinion Quarterly 63(4):508-542.

Brady, Henry E., and Paul M. Sniderman. 1985. Attitude Attribution: A Group Basis for Political Reasoning. American Political Science Review 79(4):1061-1078.

Bullock, Charles S., III. 1988. Regional Realignment from an Officeholding Perspective. Journal of Politics 50(3):553-574.

Bullock, Charles S., III, Donna R. Hoffman, and Ronald Keith Gaddie. 2006. Regional Variations in the Realignment of American Politics, 1944-2004. Social Science Quarterly 87(3):494-518.

Caldwell, Christopher. 1998. The Southern Captivity of the GOP. Atlantic Monthly 281(6):55-72.

Campbell, Angus, Philip E. Converse, Warren E. Miller, and Donald E. Stokes. 1960. The American Voter. New York: John Wiley and Sons.

Campbell, Angus, et al. 1966. Elections and the Political Order. New York: John Wiley and Sons.

Carmines, Edward G., and Harold W. Stanley. 1992. The Transformation of the New Deal Party System: Social Groups, Political Ideology, and Changing Partisanship Among Northern Whites, 1972-1988. Political Behavior 14(3):213-237.

Cash, W.J. 1941. The Mind of the South. New York: Alfred A. Knopf

Cobb, James. C. 2005. Away Down South: A History of Southern Identity. New York: Oxford University Press.

Conover, Pamela Johnston. 1988. The Role of Social Groups in Political Thinking. British Journal of Political Science 18(1):51-76.

Conover, Pamela Johnston, and Stanley Feldman. 1981. The Origins and Meaning of Liberal-Conservative Self-Identifications. American Journal of Political Science 25(4):617-644.

Cooper, Christopher A., and H. Gibbs Knotts. 2006. Region, Race, and Support for the South Carolina Confederate Flag. Social Science Quarterly 87(1):142-154.

Cooper, Christopher A., and H. Gibbs Knotts. 2012. Love 'Em or Hate 'Em? Changing Racial and Regional Differences in Opinions Toward Southerners, 1964-2008. Social Science Quarterly 93(1):58-75. 
Fiorina, Morris. 1981. Retrospective Voting in American Elections. New Haven, CT: Yale University Press.

Fischer, David Hackett. 1989. Albion's Seed: Four British Folkways in America. New York: Oxford University Press.

Green, John C. 2010. The Faith Factor. Pp. 215-232 in Presidential Election in the South:

Putting 2008 in Political Context, eds. Branwell DuBose Kapeluck, Robert P. Steed, and Laurence W. Moreland. Boulder, CO: Lynne Rienner.

Hamill, Ruth, Milton G. Lodge, and Frederick Blake. 1985. The Breadth, Depth, and Utility of Class, Partisan, and Ideological Schemata. American Journal of Political Science 29(4):850-870.

Hayes, Danny, and Seth C. McKee. 2006. Toward a One-Party South? American Politics Research 36(1):3-32.

Horwitz, Tony. 1998. Confederates in the Attic: Dispatches from the Unfinished Civil War. New York: Vintage Books.

Key, V.O. 1949. Southern Politics in State and Nation. New York: Alfred A. Knopf.

Kinder, Donald R., and Lynn M. Sanders. 1996. Divided by Color: Racial Politics and Democratic Ideals. Chicago: University of Chicago Press.

Knuckey, Jonathan. 2006. Explaining Recent Changes in the Partisan Identifications of Southern Whites. Political Research Quarterly 59(1):57-70.

Knuckey, Jonathan. 2009. Explaining Partisan Change among Northeastern Whites. Politics and Policy 37(4):1331-1355.

Kuklinski, James H., Michael D. Cobb, Martin Gilens. 1997. Racial Attitudes and the 'New South.' Journal of Politics 59(2):323-349.

Levine, Jeffrey, Edward G. Carmines, and Robert Huckfeldt. 1997. The Rise of Ideology in the Post-New Deal Party System, 1972-1992. American Politics Quarterly 25(1):19-34.

MacKuen, Michael B., Robert S. Erikson, and James A. Stimson. 1992. Peasants or Bankers? The American Electorate and the American Economy. American Political Science Review 86(3):597-611.

Marchant-Shapiro, Theresa, and Kelly D. Patterson. 1995. Partisan Change in the Mountain West. Political Behavior 17(4):359-378.

McKee, Seth C. 2010. Republican Ascendancy in Southern U.S. House Elections. Boulder, CO: Westview Press.

Miller, Arthur H., Christopher Wlezien, and Anne Hildreth. 1991. A Reference Group Theory of Partisan Coalitions. Journal of Politics 53(4):1134-1149.

Miller, Warren E., and J. Merrill Shanks. 1996. The New American Voter. Cambridge, MA: Harvard University Press.

Nossiter, Adam. 2008. For the South a Waning Hold on Politics. New York Times, November 12, http://www.nytimes.com/2008/11/11/us/politics/11south.html (accessed November 13, 2008).

Prysby, Charles L. 2006. Southern Political Party Development since World War II. Pp. 11-40 in Writing Southern Politics: Contemporary Interpretations and Future Directions, eds. Robert P. Steed and Laurence W. Moreland. Lexington: University of Kentucky Press.

Reed, John Shelton. 1986. The Enduring South: Subcultural Persistence in Mass Society. Chapel Hill: University of North Carolina Press.

Reed, John Shelton. 1993. My Tears Spoiled My Aim and Other Reflections on Southern Culture. New York: Harvest Books.

Reiter, Howard L., and Jeffrey M. Stonecash. 2011. Counter Realignment: Political Change in the Northeastern United States. New York: Cambridge University Press. 
Schaller, Thomas F. 2006. Whistling Past Dixie: How Democrats Can Win Without the South. New York: Simon and Shuster.

Schreckhise, William, and Todd Shields. 2003. Ideological Realignment in the Contemporary U.S. Electorate Revisited. Social Science Quarterly 84(3):596-612.

Shafer, Byron E., and Richard Johnston. 2006. The End of Southern Exceptionalism: Class, Race, and Partisan Change in the Postwar South. Cambridge, MA: Harvard University Press.

Speel, Robert W. 1998. Changing Patterns of Voting in the Northern United States: Electoral Realignment 1952-1996. University Park: Pennsylvania State University Press.

Stonecash, Jeffrey M., Mark D. Brewer, R. Eric Petersen, Mary P. McGuire, and Lori Beth Way. 2000. Class and Party: Secular Realignment and the Survival of Democrats Outside the South. Political Research Quarterly 53(4):731-752.

Valentino, Nicholas A., and David O. Sears. 2005. Old Times There are Not Forgotten: Race and Partisan Realignment in the Contemporary South. American Journal of Political Science 49(3):672-688.

Wilcox, Clyde, Lee Sigelman, and Elizabeth Cook. 1989. Some Like it Hot: Individual Differences in Response to Group Feeling Thermometers. Public Opinion Quarterly 53(2):246-257. 